\title{
Vertical migration, dispersal and transport of Euphausia lucens in the southern Benguela Current
}

\author{
S. C. Pillar, D. A. Armstrong, L. Hutchings \\ Sea Fisheries Research Institute, Private Bag X2, Rogge Bay 8012, Cape Town, South Africa
}

\begin{abstract}
Diurnal vertical distributions and ontogenetic migration of Euphausia lucens (Hansen) were investigated off the west coast of South Africa. Eggs and nauplii remained in the near-surface layer and did not migrate. Older larvae (calyptopes and furciliae) migrated to deeper depths during the day but were generally restricted to the upper layers of the water column. Juveniles had similar vertical distribution to adults and were capable of migrating to the bottom layers of the water column. As a result of layering and migration, different stages of $E$. lucens have different probabilities of cross-shelf and longshore transport in the southern Benguela upwelling system. Initially, wind-driven Ekman transport advects the early reproductive stages offshore where the thermal front may present a potential barrier to further offshore transport. By migrating below the near-surface layer the older stages would be more subject to longshore transport via the northward-flowing jet current. Southward transport is facilitated by the deep under-current, but penetration to the east coast of South Africa would be constrained by the influence of the Agulhas Current.
\end{abstract}

\section{INTRODUCTION}

Vertical migration is common in most euphausiid species as is ontogenetic migration whereby progressively deeper levels are occupied by older stages during the day, while during the night most of the population congregates in the upper layers of the water column (Brinton 1979, Mauchline 1980, Roe et al. 1984). A characteristic of most oceanic species is the developmental ascent, in which the eggs sink and hatch into nauplii at depth and ascend to the upper layers as firstfeeding calyptopis larvae when ontogenetic migration begins (Marr 1962, Hempel et al. 1979, Williams \& Lindley 1982). By contrast, in neritic and shelf dwelling species the eggs and nauplii have been shown to be restricted to the upper layers while the larvae and older stages migrate through different depth ranges throughout the water column (Hirota et al. 1984, Williams \& Fragopoulu 1985). The coastal environment is generally characterized by stronger horizontal and vertical circulation systems and by more complex advective processes than the oceanic environment. Neritic species would therefore have to interact with markedly different current regimes in order to maintain themselves within the coastal environment. Because of ontogenetic migration, the currents acting on early reproductive stages may be different from those acting on older larvae and adult stages. Exploitation of differential current systems associated with vertical migrations or ontogenetic layering has been proposed for other zooplankton organisms, particularly copepods, resulting in the maintenance of endemic populations (Peterson et al. 1979, Boucher 1982, 1984, Wroblewski 1982).

Ontogenetic layering has been reported for Euphausia lucens in the southern Benguela region from preliminary studies by Pillar (1984a), but information was not provided on the vertical distribution of eggs and nauplii or on the daytime distribution of juveniles and adults since they migrated below the sampling range of the net. The intentions of this study were to gain more insight into the vertical and ontogenetic distribution patterns of E. lucens and to consider what physical processes interact with these patterns to maintain the population within the southern Benguela system.

\section{METHOD AND MATERIALS}

Data were obtained from zooplankton collections from 4 cruises. The first was during October 1976 in the vicinity of Cape Point when a parachute drogue, 
set at $10 \mathrm{~m}$, was followed for $68 \mathrm{~h}$ in a northwesterly direction, covering $136 \mathrm{~km}$ (Fig. 1A). Zooplankton collections were taken at ca $8 \mathrm{~h}$ intervals using a flight of 8 'Miller nets' (Miller 1961). Each net consisted of 80 $\mathrm{cm}$ long PVC tube with an internal diameter of 14.5 $\mathrm{cm}$ and an attached $125 \mathrm{~cm}$ long cylindro-conical 300 um mesh net. The nets were distributed between the surface and $75 \mathrm{~m}$ and towed at 3 knots for $60 \mathrm{~min}$. The depth of the water column ranged from 165 to $265 \mathrm{~m}$. Details of biological and physical data collections made are presented in Shelton \& Hutchings (1982) and this collection is referred to in the text as the 'drogue cruise'.

The second cruise consisted of 2 series of $6 \mathrm{~h}$ collections in the St Helena Bay region during May 1984 and is referred to as the 'time series cruise' (Fig. 1C). At each station, zooplankton samples were collected with a $1 \mathrm{~m}^{2}$ multiple opening and closing Rectangular Midwater Trawl fitted with six $200 \mu \mathrm{m}$ meshed nets $($ RMT $1+6)$. The net was towed at 2 knots and fished in
5 depth strata during the ascent from close to the bottom to the surface. The first series (Series I), consisted of a random sampling grid designed to cover a large area of St Helena Bay, and the second series (Series II) sampled a more intensive grid covering an area of ca $1 \mathrm{n} \mathrm{mile} \mathrm{e}^{2}\left(3.2 \mathrm{~km}^{2}\right)$.

The third cruise, referred to as the 'frontal zone cruise', was designed to study the front associated with the Cape Columbine upwelling centre. These data also provided information on the inshore-offshore differences in the vertical structure of the euphausiid community. During 11 to 13 December 1984 a transect of 10 stations, $3 \mathrm{n}$ miles $(5.5 \mathrm{~km})$ apart, was sampled to within $10 \mathrm{~km}$ of the coast (Fig. 1B). Zooplankton was collected from close to the bottom to the surface in 5 depth strata, using the same method as described above for the RMT $1+6$ net. Subsequent analysis of the collections showed possible malfunctioning of the net, necessitating pooling data from the upper 2 depth strata and from the middle 2 depth strata. Since these depths were

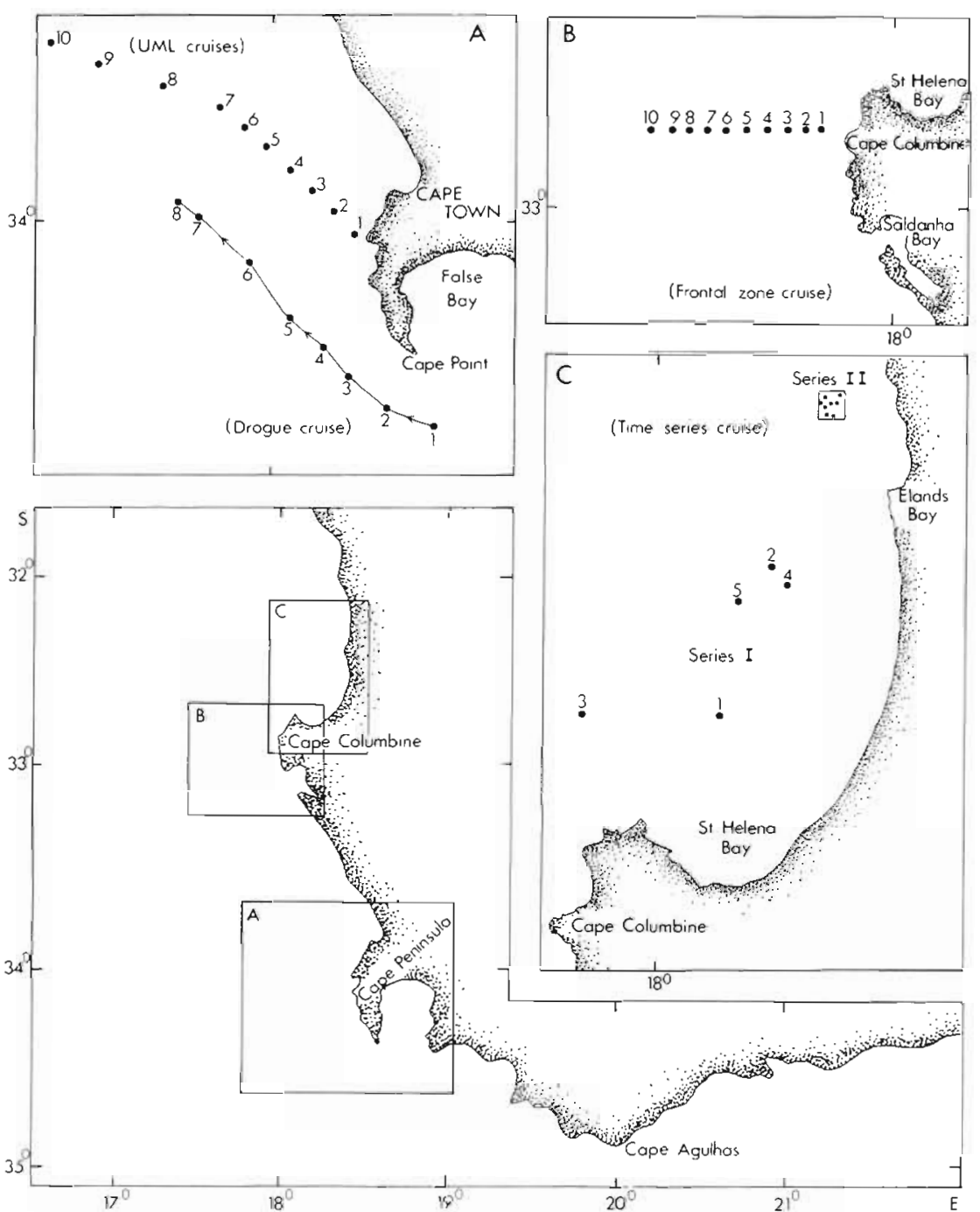

Fig. 1. Study areas off the coast of South Africa, showing stations occupied during (A) the drogue cruise and UML cruises (B) the frontal zone cruise and (C) the time series cruise 
selected on the basis of thermocline depth, the 3 strata quantitatively sampled could be considered to represent the layers above, within and below the thermocline. Details of the physical, chemical and biological sampling are described by Armstrong et al. (1987)

A fourth, 'historical' data set was drawn upon to provide information on the cross-shelf distribution of euphausiid developmental stages under contrasting hydrographic regimes. Two cruises during January and February 1973 were selected from a comprehensive monitoring programme initiated in the early 1970's. The Upwelling Monitoring Line (UML) consisted of a transect of 10 stations oriented in the general direction of the intense upwelling plume formed off the Cape Peninsula. Stns 1 to 7 were $5 \mathrm{n}$ miles $(9 \mathrm{~km})$ apart and Stns 7 to 10 were $10 \mathrm{n}$ miles $(18.5 \mathrm{~km})$ apart (Fig. $1 \mathrm{~A}$ ). Zooplankton collections were taken using a vertically hauled WP II net (Fraser 1966), fitted with a $200 \mu \mathrm{m}$ mesh net, in 2 depth strata separated by the thermocline. Details of the sampling strategy and processing are given in Andrews \& Hutchings (1980) and these collections are referred to in the text as the 'UML cruises'.

In the laboratory, counts were made of all developmental stages of Euphausia lucens, i.e. eggs, nauplii, calyptopes, furciliae, juveniles (postlarvae and immatures\} and adults. Females were examined for presence/absence of a spermatophore in the thelycum and the condition of the spermatophores in males was noted. Counts of large samples were determined from subsamples using a Folsom splitter. All counts were standardized to numbers per $\mathrm{m}^{3}$ from a knowledge of the volume of water filtered by the nets.

\section{RESULTS}

\section{Species composition}

Euphausia lucens was the dominant euphausid species in the collections from the 4 cruises. Other species which occurred infrequently were Nyctiphanes capensis which formed 0.1 and $0.3 \%$ of the euphausiid community during the drogue cruise and time series cruise, respectively, and $3 \%$ during the UML cruises. Euphausia recurva and Euphausia similis together constituted $<0.1 \%$ of the offshore euphausiid community during the frontal zone cruise.

\section{Drogue cruise}

Vertical profiles of temperature and relative abundance (percent) at depth of egg and larval stages of Euphausia lucens at each station are shown in Fig. 2.
To facilitate tracing the diel movements of each developmental stage, mean depths occupied by each stage were calculated for each station and are presented in Fig. 3. This technique was used extensively by Roe et al. (1984) and termed the Weighted Mean Depth' (WMD) which is calculated as follows:

$$
W M D=\frac{\sum n_{i} d_{i}}{N}
$$

where $d_{\mathrm{i}}=$ depth of a sample (i); $n_{1}=$ number of individuals at that depth; $N=$ sum of the number of individuals over all sampling depths.

The eggs occupied a shallower depth range than the nauplii, being concentrated in the upper $30 \mathrm{~m}$ while the bulk of the nauplii occupied the 20 to $40 \mathrm{~m}$, depth stratum (Fig. 3). Neither of these early stages showed evidence of diel movement. The calyptopis stage displayed a limited diel movement, being closer to the surface at night. The furcilia stages migrated more extensively, with a marked nocturnal ascent into the upper 20 to $30 \mathrm{~m}$ from daytime depths which extended beyond the sampling range of the net $(75$ m). The daytime WMD values for the furcilia stages (Fig. 3) are considered underestimates since the lower limits of their vertical distribution were not quantified. For the juvenile and adult stages, this limitation precluded using MWD values for tracing diel movements

The juvenile and adult stages occupied a much wider vertical range than the larval stages as evidenced by their near absence in the daytime collections (Fig. 4). This observation is not considered to be wholly a result of daytime avoidance and will be discussed later During the night adults were more numerous than juveniles in the collections with the population generally centred around the 20 to $50 \mathrm{~m}$ depth stratum. Vertical distributions of ripe males and fertilized females appeared similar to those of the sexually inactive adult population. It should be noted that the low numbers of juvenile and adults caught by the surface Miller nets during the night-time hauls may in part be attributed to the disturbance caused by the ship's movement. Through avoidance, this would decrease the euphausiids' availability to the approaching net (Pillar 1984b). The presence of a thermocline did not limit the migration of either older larvae (Fig. 2) or juvenile and adult stages (Fig. 4).

\section{Time series cruise}

Eggs and larval stages occurred infrequently in the collections and were not in sufficient numbers to allow description of their vertical distributions. The vertical distribution of the densities of Euphausia lucens 

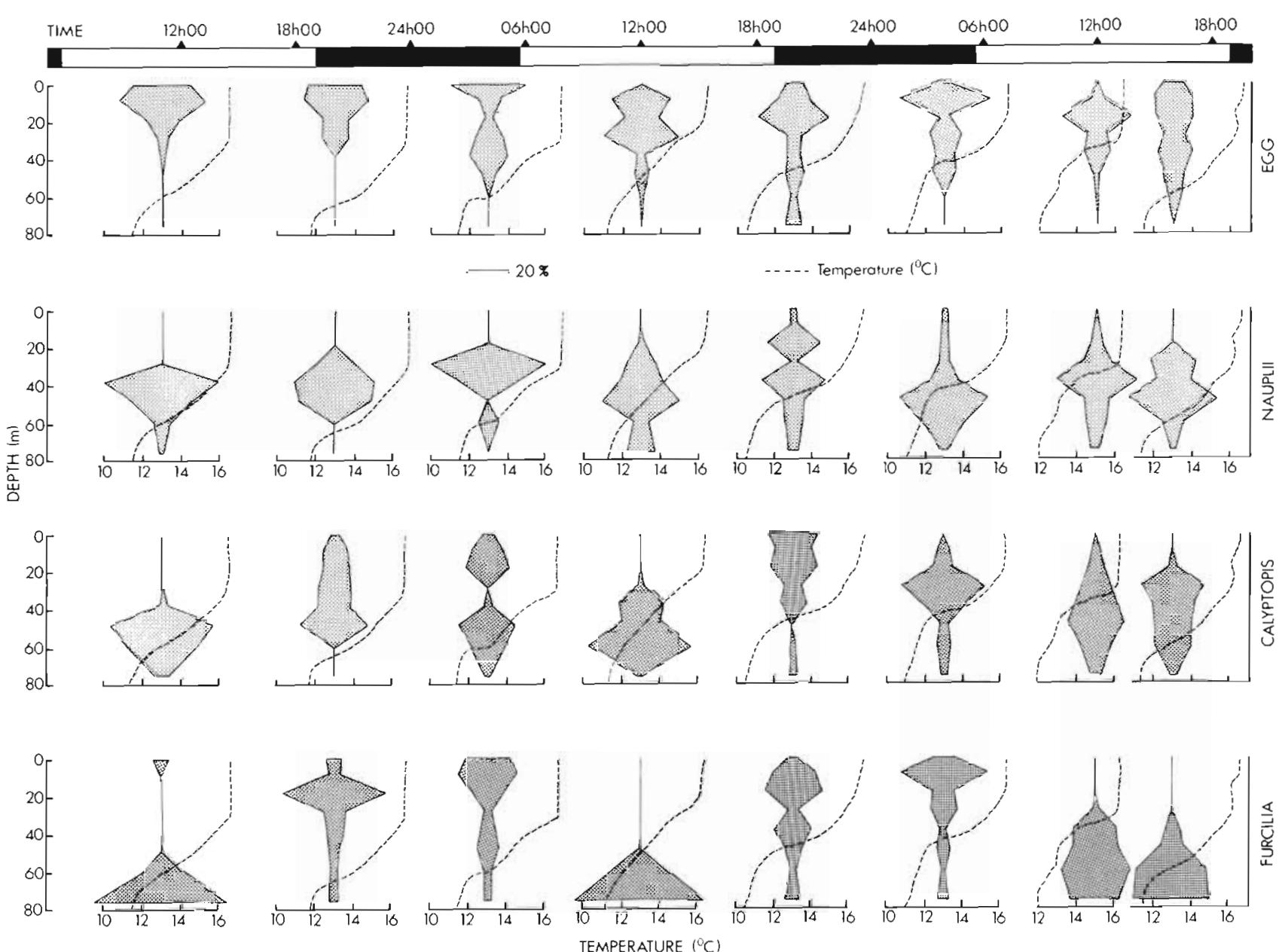

STATION NO. 1

2

3

4

5

6

7

8

Fig. 2. Euphausia lucens. Vertical distributions of egg and larval stages during the drogue cruise, Values at each depth are expressed as a percentage of the total density $\left(\right.$ no. $\mathrm{m}^{-3}$ ) over all sampling depths. Temperature is shown by a broken line

juvenile and adult stages relative to temperature was determined over 2 periods (Series I and II; Fig. 5). For comparative purposes sampling times were grouped into dawn, day, dusk and night.

In Series I highest densities were recorded throughout the water column from dusk until dawn with negligible densities occurring during the day. Juveniles occupied similar depth strata to adults. There is evidence of a shift upwards in the population after dusk and a downward shift after dawn. The near absence of juveniles and adults in the daytime collections could be due to their diel movement into the near-bottom layer, below the tracking range of the net, or to net avoidance (Brinton 1967), or to a combination of both. During a comparative study in inshore waters, Pillar (1982) showed that juveniles and adults of Euphausia lucens were more than an order of magnitude more dense within a few meters of the bottom than in a layer between 2 to $14 \mathrm{~m}$ above the bottom during the daytime. Furthermore he found similar catches of juveniles and adults in both dark and light-coloured Bongo nets during the day, indicating that avoidance associated with vision was not strongly demonstrated by E. lucens. The present data are perhaps better explained by a daytime distribution in the near-bottom layer with a nocturnal migration into the upper layers, but net avoidance cannot be entirely ruled out.

The scarcity of juveniles and adults during the day is also notable during Series $I_{\text {; }}$ however there was no apparent nocturnal ascent as observed during Series I. A possible explanation is the predatory impact of anchovy Engraulis capensis, which was present in large and dense shoals in the upper $40 \mathrm{~m}$ during Series II. Stomach analyses of these fish by James (1987) showed that they fed almost exclusively on juvenile and adult Euphausia lucens from dusk until dawn. During the day they were absent in the 
stomachs, although copepod remains were present. This feeding pattern suggests that the euphausiids were not present in the upper $40 \mathrm{~m}$ during the day, providing additional support to the contention that E. lucens migrated into the bottom layers during the day.

\section{Frontal zone cruise}

The samples collected during this cruise give some indication of the depth strata occupied by the different developmental stages of Euphausia lucens in inshore and offshore waters. However the offshore data should be viewed with some caution since a much greater depth range was sampled by the bottom nets than the surface nets. Hence when standardized to numbers per $\mathrm{m}^{3}$ the abundance estimates of the bottom stratum will have artificially lower estimates relative to the shallower depth strata if the euphausiids were not evenly distributed with depth. However in Fig. 6, which shows the vertical distribution of the egg and larval stages with distance offshore, several features are apparent which are not masked by this bias. Marked changes in the relative abundance and vertical distribution occurred with distance offshore and with depth. The eggs and nauplii were concentrated

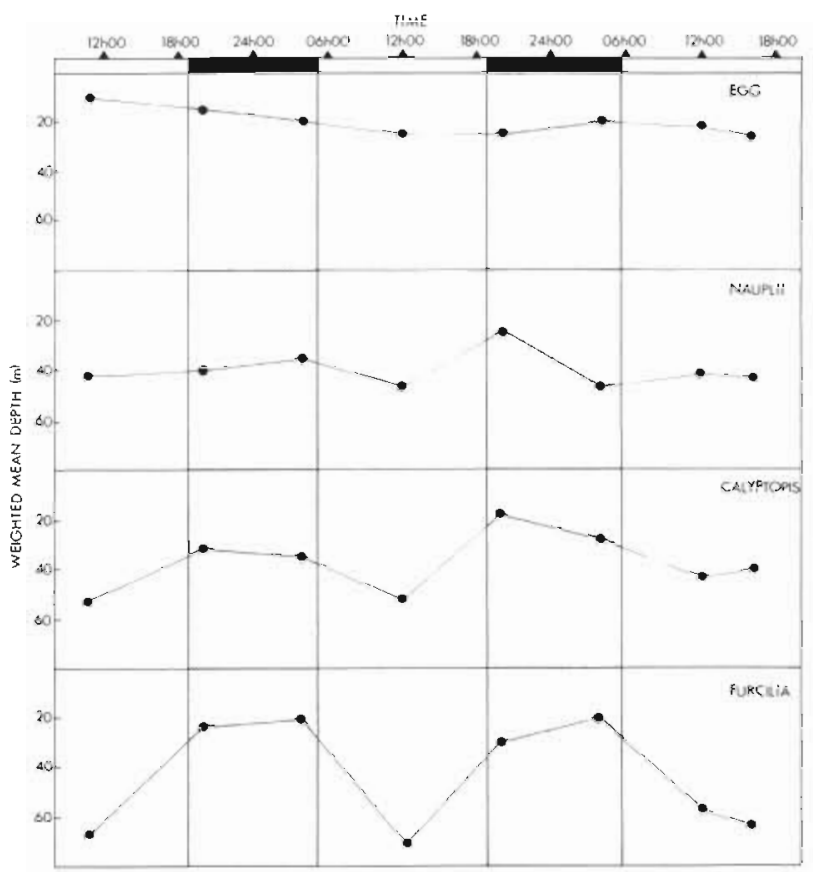

Fig. 3. Euphausia lucens. Weighted mean depth plots of egg and larval stages during the drogue cruise
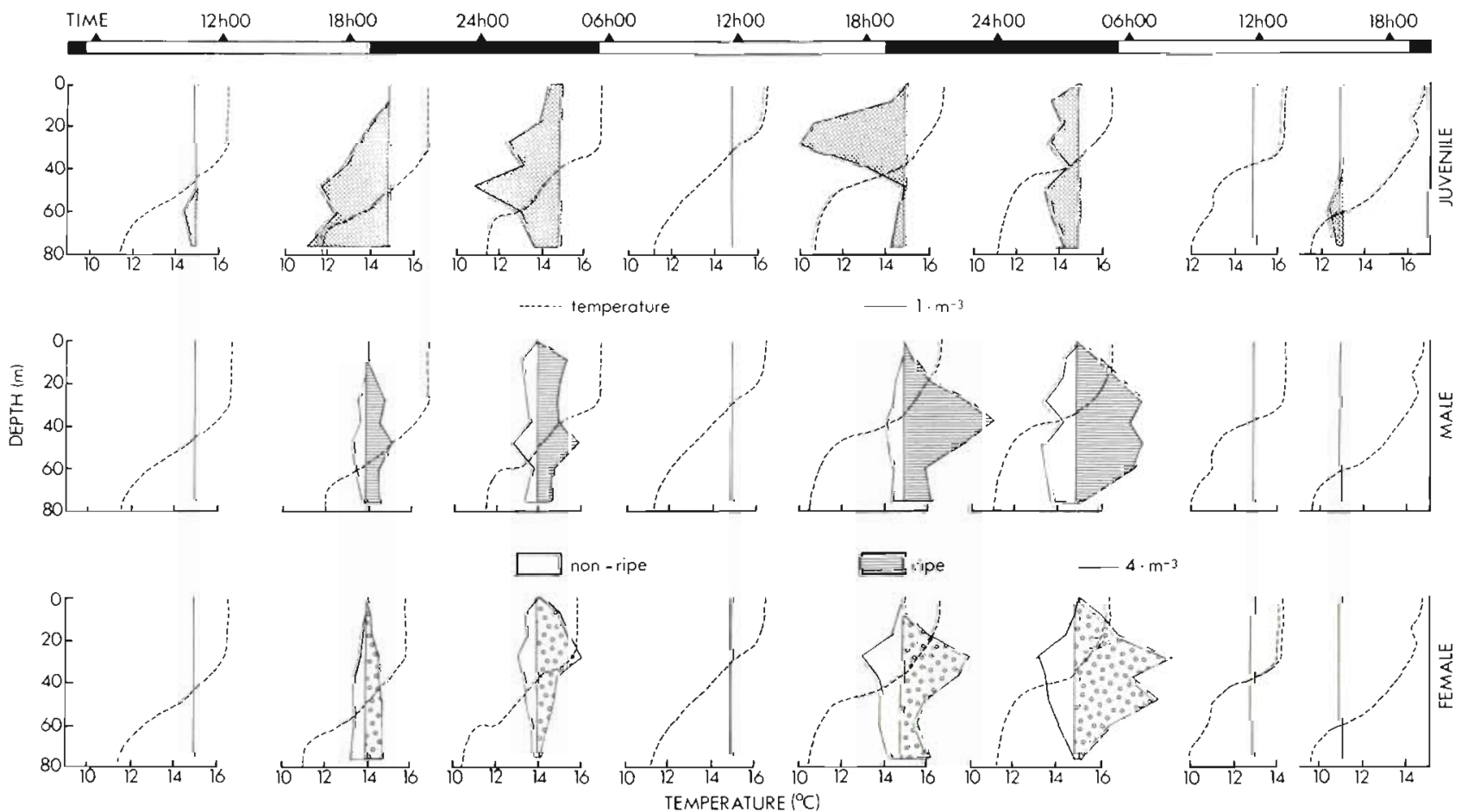

STATION NO.
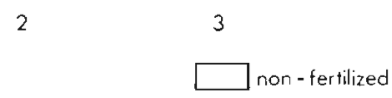

4

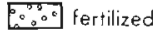

$-4 \cdot \mathrm{m}^{-3}$

Fig. 4. Euphausia lucens. Vertical distributions of juvenile and adult stages during the drogue cruise. Temperature is shown by a broken line 


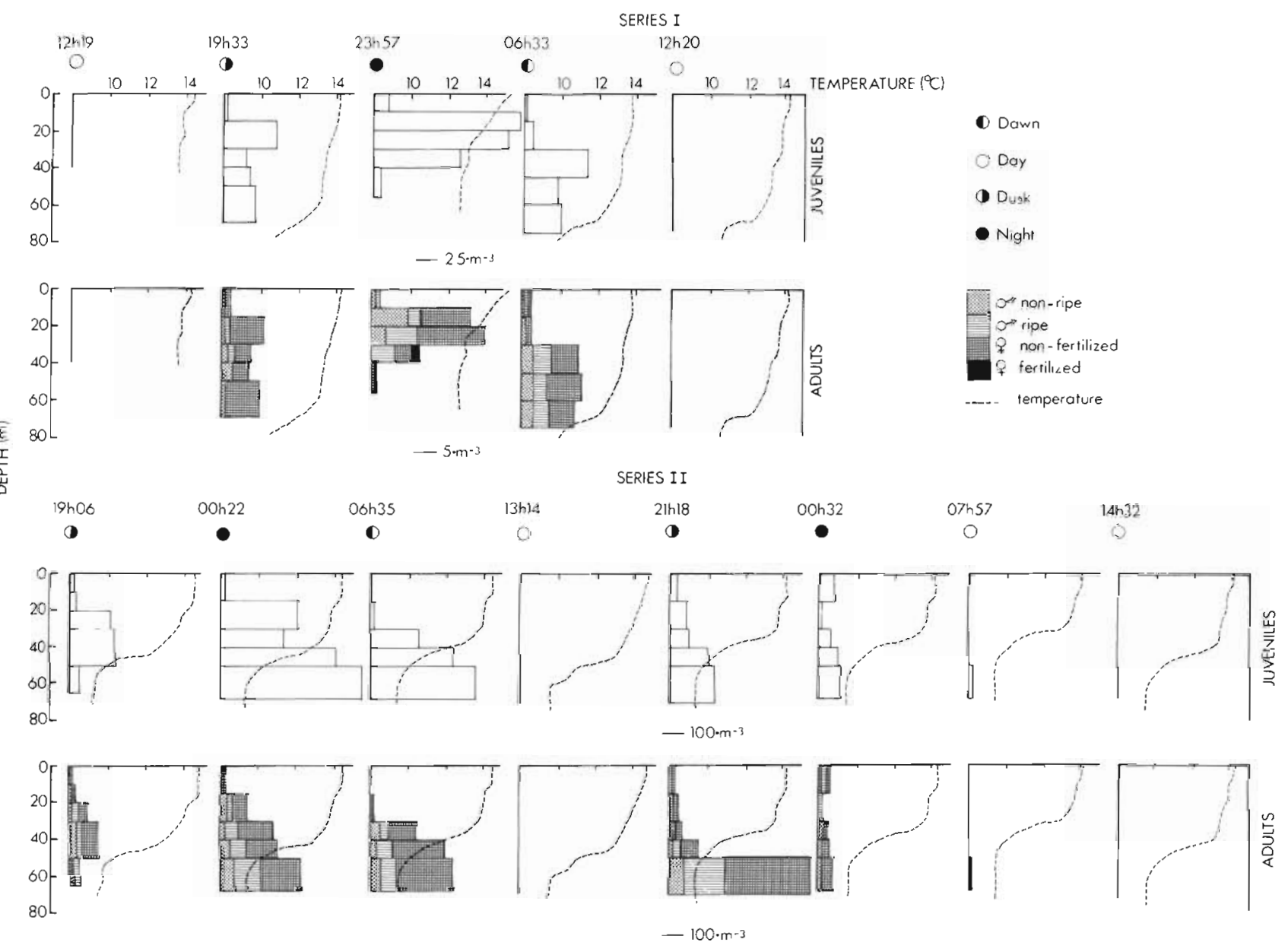

Fig. 5. Euphausia lucens. Vertical distribution of juvenile and adult stages during Series I and II of the time series cruise. Temperature is shown by a broken line

in the vicinity of the front while the highest densities of the calyptopes and furciliae larvae were closer inshore. Densities declined markedly in the offshore zone. The eggs and larvae occupied the upper strata during both day and night offshore, but were distributed throughout the water column at the shallower inshore stations.

The abundance of the juvenile and adult stages of Euphausia lucens was highly variable along the transect as a result of their scarcity in the daytime collections (Fig. 7). They occupied similar depth strata from dusk to dawn within a vertical range more extensive than the younger developmental stages. There is evidence of an upward and downward shift in the population during this period.

\section{UML cruises}

These data illustrate the influence of contrasting hydographic regimes on the horizontal displacement of the early life stages of euphausiids. The juveniles and adults are not quantitatively sampled by the WPII net (Pillar 1984b) and were therefore not considered in this analysis.

Sampling in January 1973 was during a quiescent phase of the upwelling cycle following a relaxation in the upwelling-favourable wind stress. In contrast, sampling during February 1973 occurred after a period of sustained southeasterly winds giving rise to coastal upwelling. The biological, physical and chemical parameters measured during these 2 studies can be found in Olivieri (1983) and Hutchings et al. (1986). Euphausiid egg, nauplius and calyptopis stages were restricted to the upper layer, with the exception of the inner 2 stations sampled during the quiescent phase when eggs and nauplii were distributed throughout the water column. Furcilia stages were generally encountered $(>70 \%)$ above the thermocline. Consequently the data presented are those from collections taken from the thermocline to the surface.

Fig. 8 illustrates the centres of abundance of the 


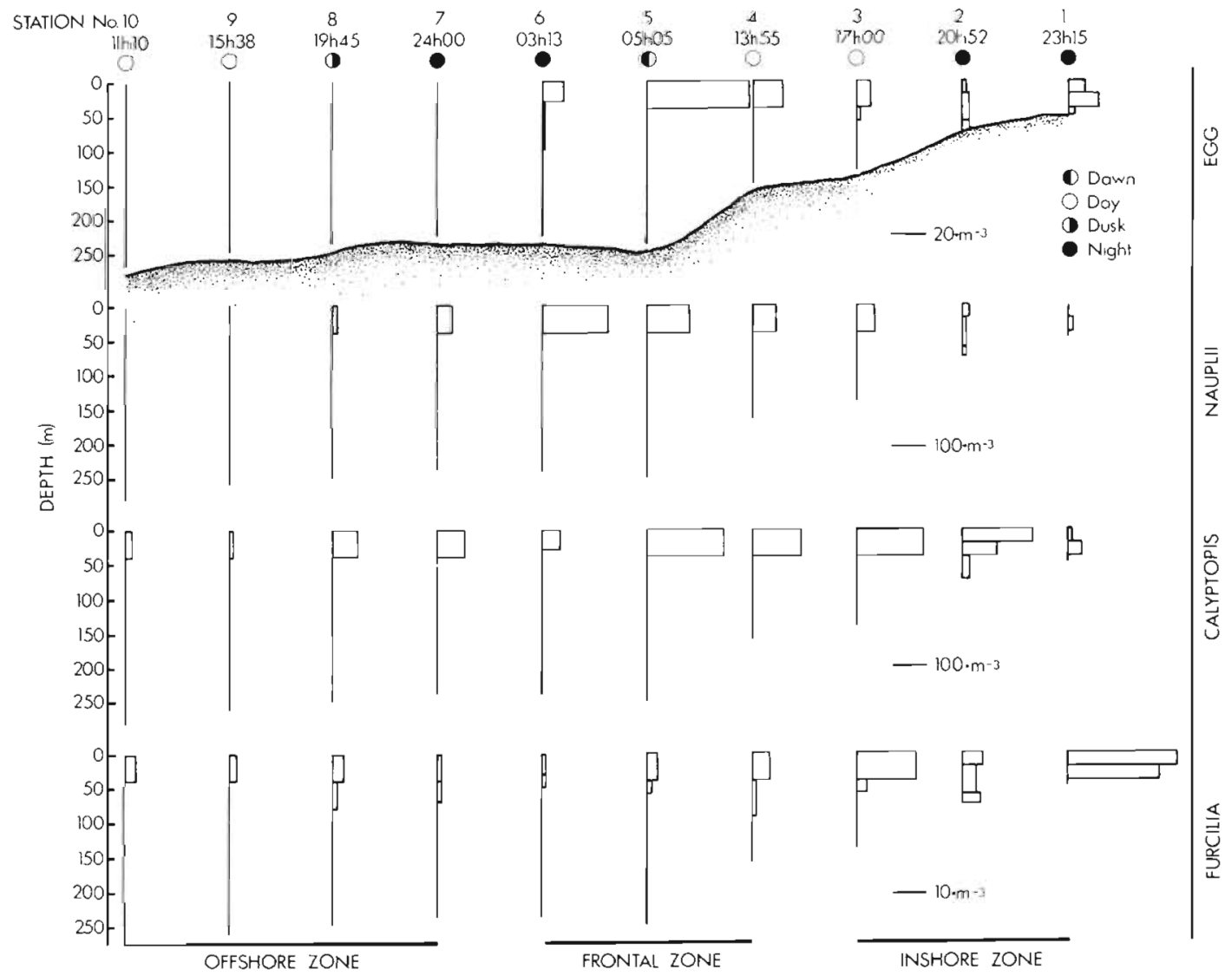

Fig. 6. Euphausia lucens. Vertical distribution of eggs and larval stages during the frontal zone cruise

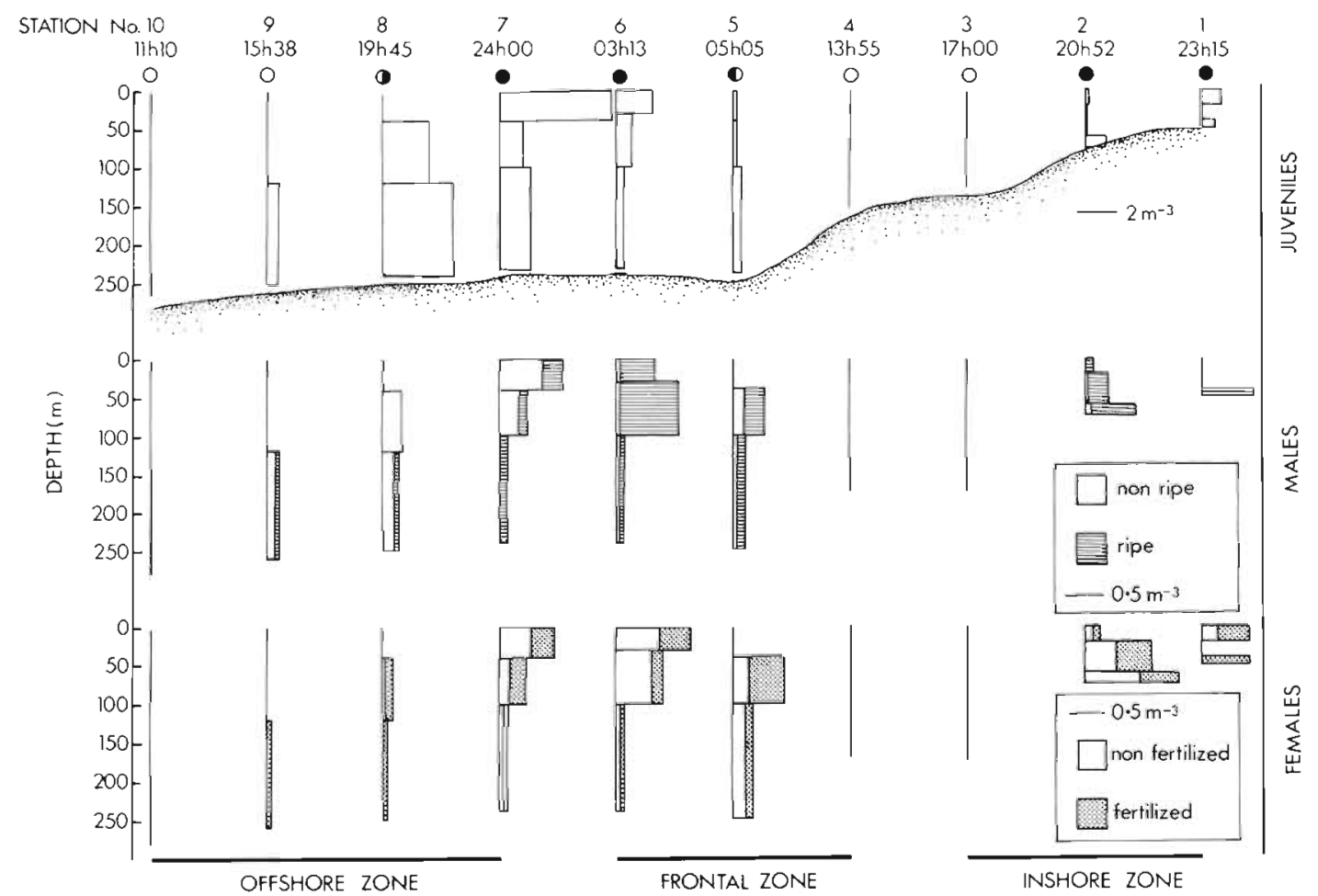

Fig. 7. Euphausia lucens. Vertical distribution of juvenile and adult stages during the frontal zone cruise 


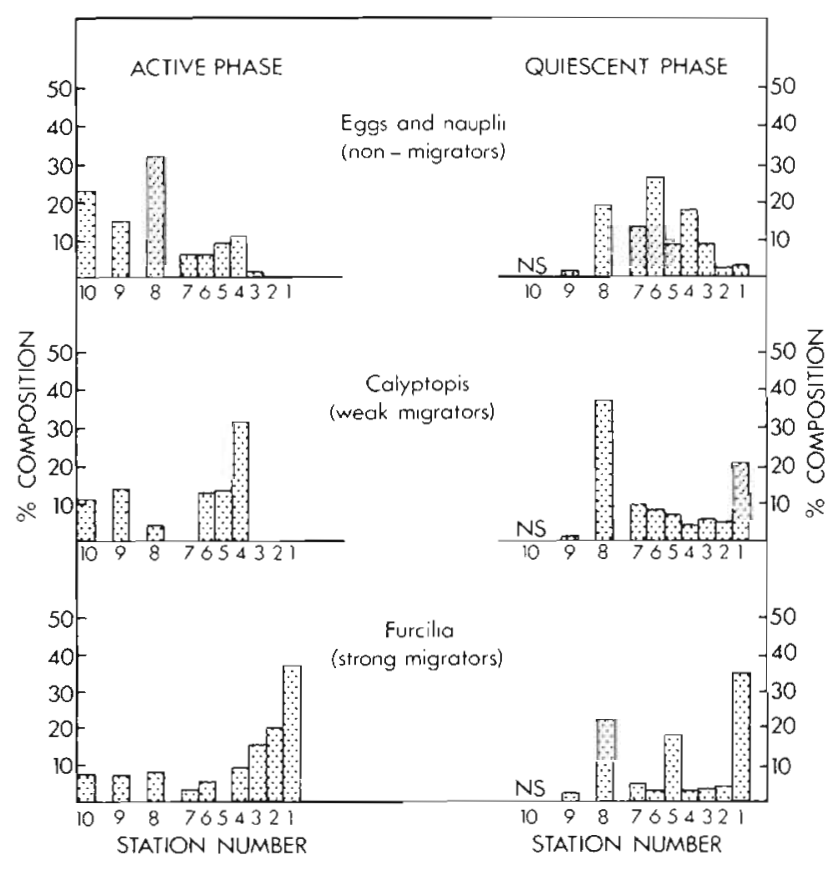

Fig. 8. Horizontal distribution of the early developmental stages of euphausiids along the Upwelling Monitoring Line during active (February 1973) and quiescent (January 1973) phases of upwelling off the Cape Peninsula. NS: 'not sampled'

different developmental stages along the transect during the 2 phases of the upwelling cycle. The eggs, nauplii and calyptopes occupied a more offshore distribution during active upwelling than during the quiescent phase. Conversely the furcilia larvae maintained a pronounced inshore distribution in the presence of active upwelling, with an offshore shift in distribution during the quiescent phase.

\section{DISCUSSION}

\section{Vertical distribution}

The eggs of Euphausia Iucens were restricted to the near-surface layers, suggesting slower sinking rates than those of oceanic species. Laboratory studies by Marschall (1983) showed that under similar temperature and salinity regimes eggs of neritic species, such as Meganyctiphanes norvegica and Thysanoessa rachii, had slower sinking rates than Euphausia superba, a typical oceanic species. Harrington \& Thomas (1987) noted that the eggs of Euphausia crystallorophias, a neritic species, were neutrally buoyant and suggested that a proportionately large perivitelline space in the egg would decrease its sinking rate. They calculated that the proportion of the total egg volume occupied by the perivitelline space in E. crystallorophias and other neritic species ranged between 44.7 to $77.7 \%$, a much larger value than the 6.4 to $13.0 \%$ computed for $E$. superba. In support of their finding they noted that the perivitelline space of Thysannoessa longicaudata, an oceanic species, was reported by Williams \& Lindley (1982) to be 'very small'. From samples taken from a number of depth strata the perivitelline space of $E$. lucens eggs was estimated to be $62.7 \pm 4.8 \%(n=50)$ of the total egg volume. This result supports the conclusions of Harrington \& Thomas (1987).

The fact that the nauplius stages of Euphausia Iucens were concentrated at shallow depths is evidence that the ontogenetic migration of neritic species is different from the classical 'developmental ascent' characteristic of oceanic species in which the eggs sink, hatch at depth and ascend to the surface layers as first-feeding calyptopis larvae (Marr 1962; Mauchline 1980; Williams \& Lindley 1982). This difference in ontogenetic behavior was noted in the Scotia Sea by Makarov (1979) who found nauplius stages of Euphausia crystallorophias in the upper $25 \mathrm{~m}$ while similar stages of Euphausia superba and Thysanoessa macrura, both oceanic species, were concentrated at depths of between 500 and $1000 \mathrm{~m}$. The author related this finding to the hydrology of inshore waters as well as to difference in the spawning behavior of neritic species.

The observed ontogenetic migrations in Euphausia lucens, with the older furcilia larvae migrating more extensively than the younger calyptopis larvae is a common feature in most euphausiid species (Mauchline \& Fisher 1969; Mauchline 1980; Williams \& Lindley 1982; Hirota et al. 1984). It is evident that the developmental cycle from egg through to the beginning of adolesence of $E$. lucens takes place within the upper layers, except in shallow waters where turbulence may cause mixing of the water column as observed during the frontal zone cruise (Armstrong et al. 1987). There are several advantages to remaining in the upper layers during early development. Firstly, relatively less energy need be invested in the eggs by the adults, as non-feeding nauplii are not required to migrate from the bottom layers to reach the surface layers as firstfeeding larvae. Secondly, by remaining in the warmer upper mixed layer faster egg and nauplii development would result in increased early survival.

\section{Dispersal and transport}

The ontogenetic migration of Euphausia lucens is extensive enough to carry them to strata of the water column with different current regimes such that currents acting on the eggs and nauplii would be different from those acting on the older larvae and juvenile and adult stages. Nelson \& Hutchings (1987) concluded that prevailing currents in the southern Benguela are of 
sufficient strength to passively transport pelagic organisms with swimming speeds $<30 \mathrm{~cm} \mathrm{~s}^{-1}$. Also Brown \& Hutchings (1987) showed that newly upwelled nearsurface water moved at speeds between 20 and $40 \mathrm{~cm}$ $\mathrm{s}^{-1}$. These values are greater than the range of mean active swimming speeds $\left(0.6\right.$ to $\left.0.9 \mathrm{~cm} \mathrm{~s}^{-1}\right)$ estimated for adult Euphausia pacifica (Torres \& Childress 1983), and the maximum swimming speeds recorded from field and laboratory experiments $\left(6.3\right.$ and $9.5 \mathrm{~cm} \mathrm{~s}^{-1}$ respectively) for Euphausia mucronata (Antezana 1978). Therefore it may be assumed that all stages of $E$. lucens, especially early larval stages, are subject to passive transport by local currents. However, as cautioned Nelson \& Hutchings (1987), current speeds are variable on time scales of hours and therefore movement against averaged currents may be possible for older stages of E. lucens.

The cross-shelf distributions observed during the 2 phases of the upwelling cycle suggest a complex transfer both onshore and offshore during development (Fig. 8). The various stages of euphausids have abundance maxima at different localities across the shelf as a consequence of their vertical distribution within the water column and the prevailing currents encountered there. During active upwelling, eggs and nauplii are found offshore, calyptopes midshelf, and furcilia larvae nearshore. Shoreward transfer of eggs and nauplii occurs during relaxation of upwelling with an offshore shift in the centre of abundance of the deeper dwelling stages. The later winter to early summer spawning of Euphausia lucens (Pillar \& Stuart 1988) places the eggs in the surface layers of the southern Benguela region during the period of strengthening of the thermal front, resulting from seasonal upwelling during which increased Ekman transport occurs (Shannon 1985). The extent of this offshore transport of the early reproductive stages may be influenced by the thermal front, which seems to exert some control on their offshore displacement (Fig. 6). The thermal front has been implicated as a barrier to the offshore Ekman transport of shelf water along the west coast (Hutchings et al. 1986, Shelton 1986). Peaks of copepod eggs, nauplii and copepodite stages have also been recorded in the surface layers adjacent to fronts in the southern Benguela region (Hutchings et al. 1986, Armstrong et al. 1987 ) and elsewhere (Boucher 1984, Scrope-Howe \& Jones 1985, Smith et al. 1986). The frontal zone may therefore provide a favourable habitat for the development and onset of first feeding for the euphausiid larvae. Brinton (1985) has documented the importance of fronts in influencing the distribution and development of larval stages of euphausiids in the Antarctic.

Since older larvae of Euphausia lucens spend proportionately less time in the surface layers than the eggs and nauplii, and migrate to greater depths during the day, they are less susceptible to offshore transport and more subject to the currents underlying the surface layers. These currents are predominantly longshore. Nelson \& Hutchings (1987) reviewed salient features from drogue studies (Shelton \& Hutchings 1982, Nelson \& Hutchings 1983, Holden 1985, Nelson 1985) and current meter studies (Nelson 1983, Holden 1987, Nelson \& Polito 1987) and proposed a longshore-closure system between the Agulhas Bank and St Helena Bay. This model provides a useful basis for examining some of the mechanisms by which E. lucens could be maintained within the southern Benguela system. The important features contributing to this current closure system are: (1) the near-surface northward-flowing jet current which rounds Cape Point from the Agulhas Bank and attenuates north of Cape Columbine; (2) the cyclonic gyre and associated eddies in the St Helena Bay region where the residence time of the water is substantial, on the order of $25 \mathrm{~d}$ (Waldron 1985); (3) the barotropic southward-flowing current which occurs inshore along the west coast. These features are summarized in the schematic model presented in Fig. 9

The resultant effect of offshore displacement coupled with the jet current would facilitate northward movement of young stages (eggs and nauplii) if spawning occurred south of St Helena Bay. Near this region there is a divergence zone, which provides alternative mechanisms to the northward displacement of material, either into the St Helena Bay area or further north into the Namaqua region. The cyclonic eddy into St Helena Bay has been suggested to be more intensive during summer and the northward component to be more prevalent during winter and spring (Shelton 1986). This implies that a significant proportion of the early reproduction stages of Euphausia lucens would be transported past St Helena Bay and out of the closure system described by Nelson \& Hutchings (1987). However, larvae of E. lucens may not necessarily be lost to the southern Benguela region as smaller closure systems, suggested by Nelson \& Hutchings (1987) to exist further north, could entrain them towards the coast. Recent data on anchovy recruitment distributions along the west coast suggests that the Orange River area is a major retention zone (Hampton 1987). Upwelling centres exist where the shelf narrows along the west coast at Hondeklip Bay and Lüderitz (Fig. 9). The increased onshore flow at depth at these regions would aid the return of material to the coast. The deeper vertical migration of older larvae, coupled with the poleward deep countercurrent would facilitate a return mechanism of E. lucens into the southern Benguela closure system.

Material transported beyond Lüderitz would, in all probability, be lost from the southern Benguela population. Satellite drogue studies described by Nelson \& 


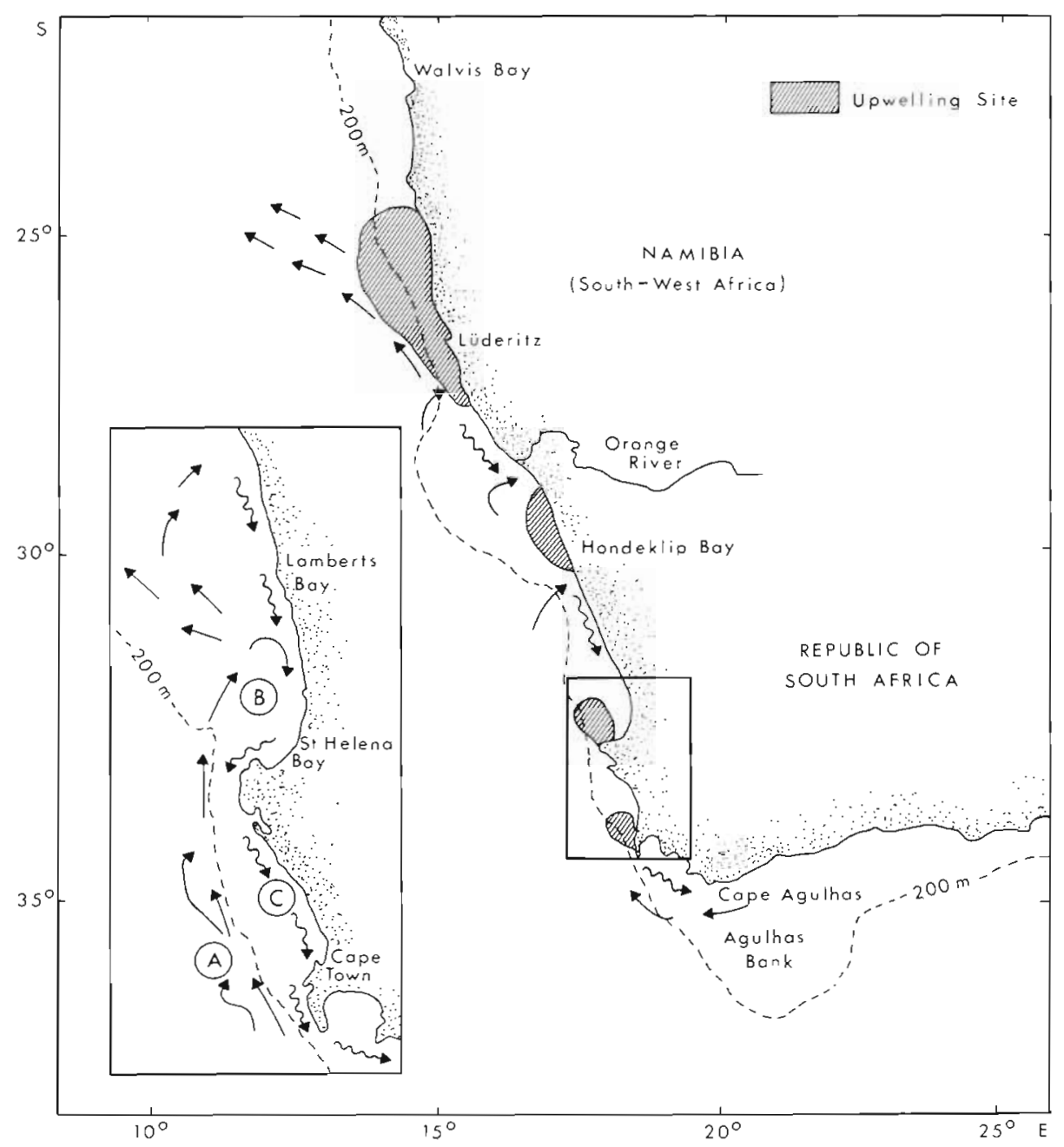

Fig. 9. Schematic representation of currents between Cape Agulhas and Lüderitz. Currents north of Lambert's Bay are assumed from indirect evidence. Key elements are $A$ : the baroclinic jet current; $B$ : the cyclonic gyre; and $C$ : the wavelike countercurrent. From Nelson \& Hutchings $(1983,1987)$
Hutchings (1983) showed a westward-moving flow off the shelf zone southwest of Lüderitz into Namibian oceanic waters. Although faunistic studies on euphausiids in Namibian waters are rare, there is convincing evidence that a faunal barrier exists at the Lüderitz upwelling zone some $600 \mathrm{~km}$ north of St Helena Bay, as north of this region Euphausia lucens is very scarce and Nyctiphanes capensis becomes the dominant euphausiid species (Boden 1955, D'Arcangues 1977). This zone has been implicated as an environmental barrier to the northward extension of several species of chaetognaths (Venter 1969), pelagic fish shoals (Agenbag 1980) and fish larvae (O'Toole 1977, Le Clus 1985). Agenbag \& Shannon (1988) used physical data to show that a biological discontinuity zone could exist just north of Lüderitz in the vicinity of Meob Bay $\left(24^{\circ} 30^{\prime} \mathrm{S}\right)$. As the influence of the Lüderitz region on the St Helena Bay area seems to be largely restricted to the subsurface countercurrent (Shannon 1985), it is suggested that individuals not entrained into this system would be transported further north and off the productive shelf region into oceanic waters where mortality would be high.

The eastward penetration of Euphausia lucens past Cape Point and into the Agulhas Bank region would be strongest in winter when the influence of the Agulhas Current is weakest (Shannon 1985). Eggs resulting from early spawning (August) on the Agulhas Bank may drift eastwards but later spawning during the spring and summer would increase the possibility of the eggs being transported around Cape Point and up the west coast in the jet current. Work by Talbot (1974) east of the Agulhas Bank suggests this. She found larvae and adult stages of $E$. lucens as far east as Port Elizabeth $\left(34^{\circ} \mathrm{S} 26^{\circ} \mathrm{E}\right)$ during winter (August) collections but during summer (FebruaryMarch) and autumn (May) E. lucens was absent from her collections. She concluded that this species was not indicative of the Agulhas Current zooplankton community.

Studies on the basis of vertical migration of Euphausia lucens may therefore have value in con- 
tributing towards an understanding of their dispersal and transport. The proposed current-closure scheme, whereby early near-surface dwelling reproductive stages are advected offshore during upwelling, transported northwards and returned southward at depth seems a likely mechanism whereby $E$. lucens can remain and develop high concentrations within the southern Benguela upwelling system (Pillar 1986, Verheye \& Hutchings 1988).

Acknowledgements. We thank the Director of the Sea Fisheries Research Institute (SFRI) South Africa for funds and facilities for this research. We wish to thank Prof. J. G. Field (University of Cape Town) for his guidance and valuable comments on various versions of the manuscript. We also thank the staff of the SFRI for their technical assistance and to the officers and crew of the various ships used throughout the project.

\section{LITERATURE CITED}

Agenbag, J. J. (1980). General distribution of pelagic fish off South West Africa as deduced from aerial fish spotting (1971-1974 and 1977) and as influenced by hydrology. Fish. Bull. S. Afr. 13: 55-67

Agenbag, J. J., Shannon, L. V. (1988). A suggested physical explanation for the existence of a biological boundary at $24^{\circ}$ $30^{\prime} \mathrm{S}$ in the Benguela system. S. Afr. J. mar. Sci. 6: 119-132

Andrews, W. R. H., Hutchings, L. (1980). Upwelling in the southern Benguela Current. Prog. Oceanogr 9: 1-81

Antezana, T. (1978). Distribution of euphausiids in the ChilePeru Current with particular reference to the endemic Euphausia mucronata and the oxygen minima layer. Ph. D. thesis, University of California

Armstrong, D. A., Mitchell-Innes, B. A., Verheye-Dua, F. Waldron, H., Hutchings. L. (1987). Physical and biological features across an upwelling front in the southern Benguela. In: Payne, A. I. L., Gulland, J. A., Brink, K. H. (eds.) The Benguela and comparable ecosystems. S. Afr. J. mar Sci. 5: 171-190

Boden, B. P. (1955). Euphausiacea of the Benguela Current. First survey, R. R. S. William Scoresby, March 1950. 'DisCovery' Rep. $27 \cdot 339-376$

Boucher, J. (1982). Peuplement de copepodes des upwellings côtiers Nord-Quest africains 11 - Maintien de la localisation spatiale. Oceanologica Acta 5: 199-207

Boucher, J. (1984). Localization of zooplankton population in the Ligurian marine front: role of ontogenic migration. Deep Sea Res. 31: 469-484

Brinton, E. (1967). Vertical migration and avoidance capability of euphausiids in the California current. Limnol. Oceanogr. 12: $451-483$

Brinton, E. (1979). Parameters relating to the distributions of planktonic organisms, especially euphausiids in the eastern tropical Pacific. Prog. Oceanogr. 8: 125-189

Brinton, E. (1985). The oceanographic structure of the eastern Scotia Sea - III. Distributions of euphausiid species and their developmental stages in 1981 in relation to hydrography. Deep Sea Res. 32: 1153-1180

Brown, P. C. Hutchings, L. (1987). The development and decline of phytoplankton blooms in the southern Benguela upwelling system. 1. Drogue movements, hydrography and bloom development. In: Payne, A. I. L., Gulland, J. A., Brink, K. H. (eds.) The Benguela and comparative ecosystems. S. Afr. J. mar Sci. 5: 357-391
D'Arcangues, C. (1977). Sound-scattering layers in neritic waters off South West Africa. Annls Inst. océanogr., Paris 53: $87-104$

Fraser, J. H. (1966). Zooplankton sampling. Nature, Lond. 211 (5052): 915-916

Hampton, I. (1987). Acoustic survey on the abundance and distribution of anchovy spawners and recruits in South African waters. In: Payne, A. 1. L., Gulland, J. A., Brink, K. H. (eds.) The Benguela and comparable ecosystems. S. Afr. J. mar. Sci. 5: 901-917

Harrington, S. A., Thomas, P. G. (1987). Observations on spawning by Euphausia crystallorophias from waters adjacent to Enderby Land (East Antarctica) and speculations on the early ontogenetic ecology of neritic euphausiids. Polar Biol. 7: 93-95

Hempel, I., Hempel, G., Baker, A de C. (1979). Early life history stages of krill (Euphausia superba) in Bransfield Strait and Weddel Sea. Meeresforschung 27: 267-281

Hirota, Y., Nemoto, T., Marumo, R. (1984). Vertical distribution of larvae of Euphausia nana and E. similis (Crustacea: Euphausiacea) in Sagami Bay and Suruga Bay, Central Japan. Mar. Biol. 81. 131-137

Holden, C. J. (1985). Currents in St. Helena Bay inferred from Radio-Track Drifters. In: Shannon, L. V (ed.) South African ocean colour and upwelling experiment. Sea Fisheries Research Institute, Cape Town, p. 97-109

Holden, C. J. (1987). Observations of low frequency currents and continental shelf waves along the west coast of South Africa In: Payne, A. I. L., Gulland, J. A., Brink, K. H. (eds.) The Benguela and comparative ecosystems. S. Afr. J. mar. Sci 5: $197-208$

Hutchings, L., Armstrong, D. A., Mitchell-Innes, B. A. (1986). The frontal zone in the southern Benguela Current. In: Nihoul, J. C. J. (ed.) Marine interfaces ecohydrodynamics. Elsevier, Amsterdam, p. 67-94

James, A. G. (1987). Feeding ecology, diet and field-based studies on feeding selectivity of the Cape anchovy Engraulis capensis Gilchrist. In: Payne, A. I. L., Gulland, J. A., Brink, K. H. (eds.) The Benguela and comparative ecosystems. S. Afr. J. mar Sci. 5: 673-692

Le Clus, F. (1985). The spawning of anchovy, Engraulis capensis Gilchrist, off South West Africa. M. Sc. thesis, University of Port Elizabeth, South Africa

Makarov, R. R. (1979). Larval distribution and reproductive ecology of Thysanoessa macrura (Crustacea:Euphausiacea) in the Scotia Sea. Mar. Biol. 52: 377-386

Marr, J. W. S. (1962). The natural history and geography of the Antarctic krill (Euphausia superba Dana). 'Discovery' Rep. 32: $33-464$

Marschall, H. P. (1983). Sinking speed, density and size of euphausiid eggs. Meeresforschung 30: 1-9

Mauchline, J. (1980). The biology of mysids and euphausiids In: Blaxter, J. H. S., Russel, F. S., Yonge, M. (eds.) Advances in marine biology 18. Academic Press, London, $p$ $1-681$

Mauchline, J., Fisher, L. R. (1969). The biology of euphausiids In: Russel, F. S., Yonge, M. (eds.) Advances in marine biology 7. Academic Press, London, p. 1-454

Miller, D. (1961). A modification of the small Hardy plankton sampler for simultaneous high speed plankton hauls. Bull. Bingham oceanogr Coll. 12: 1-97

Nelson, G. (1983). Circulation over the shelf zone of the Cage Peninsula region. S. Afr. J. Sci. 79 (4): 147 (Abstract only)

Nelson, G. (1985). Notes on the physical oceanography of the Cape Peninsula upwelling system. In: Shannon, L. V. (ed.) South African ocean colour and upwelling experiment Sea Fisheries Research Institute, Cape Town, p. 63-95 
Nelson, G., Hutchings, L. (1983). The Benguela upwelling area. Prog. Oceanogr 12: 333-356

Nelson, G., Hutchings, L. (1987). Passive transportation of pelagic system components in the southern Benguela area. In: Payne, A. I. L., Gulland, J. A., Brink, K. H. (eds.) The Benguela and comparable ecosystems. S. Afr. J. mar. Sci. 5: $223-234$

Nelson, G., Polito, A. (1987). Information on currents in the Cape Peninsula area, South Africa. In: Payne, A. I. L., Gulland, J. A., Brink, K. H. (eds.) The Benguela and comparative ecosystems. S. Afr. J. mar Sci. 5: 287-304

Olivieri, E. T. (1983). A description of the hydrography and phytoplankton communities in the upwelled waters of the Cape Peninsula, South Africa, September 1972 - February 1973. S. Afr. J. mar. Sci. 1: 199-299

O'Toole, M. J. (1977). Investigations into some important fish larvae in the South East Atlantic in relation to the hydrological environment. $\mathrm{Ph}$. D. thesis, University of Cape Town

Peterson, W T., Miller, C. B., Hutchinson, A. (1979). Zonation and maintenance of copepod populations in the Oregon upwelling zone. Deep Sea Res. 26: 467-494

Pillar, S. C. (1982). A comparison of the performance of four zooplankton samplers with notes on the diurnal movement of some common zooplankton species off the west coast of South Africa. M. Sc thesis, University of Cape Town

Pillar, S. C. (1984a). Diel variation in the vertical distribution of some common zooplankton species off the west coast of South Africa. S. Afr. J. mar. Sci. 2: 71-80

Pillar, S. C. (1984b). A comparison of the performance of four zooplankton samplers. S. Afr. J. mar. Sci. 2: 1-18

Pillar, S. C. (1986). Temporal and spatial variations in copepod and euphausiid biomass off the southern and south-western coasts of South Africa in 1977/78. S. Afr. J. mar. Sci. 4: 219-229

Pillar, S. C., Stuart, V (1988). Population structure, reproductive biology and maintenance of Euphausia lucens in the southern Benguela Current. J. Plankton Res. 10: $1083-1098$

Roe, H. S. J., Angel, M. V., Bradcock, J., Domanski, P., James, P. T., Pugh, P. R., Thurston, M. H. (1984). The diel migrations and distributions within a mesopelagic community in the North East Atlantic. Prog. Oceanogr. 13: 425-460

Scrope-Howe, S., Jones, D. A. (1985). Biological studies in the vicinity of a shallow-sea tidal mixing front. 5. Composition,

This article was submitted to the editor abundance and distribution of zooplankton in the western Irish Sea. April 1980 to November 1981. Phil. Trans. R. Soc. Lond. Ser. B 310: 501-519

Shannon, L. V (1985). The Benguela ecosystem. 1 Evolution of the Benguela, physical features and processes. In: Barnes, $M$. (ed.) Oceanography and marine biology. An annual review 23. University Press, Aberdeen, p. 105-182

Shelton, P. A. (1986). Fish spawning strategies in the variable southern Benguela Current region. Ph. D. thesis, University of Cape Town

Shelton, P. A., Hutchings, L. (1982). Transport of anchovy, Engraulis capensis Gilchrist, eggs and early larvae by a frontal jet current. J. Cons. int. Explor Mer. 40: 185-198

Smith, S. L., Jones, B. H., Atkinson, L. P., Brink, K. H. (1986). Zooplankton in the upwelling fronts off $\mathrm{Pt}$. Conception, California. In: Nihoul, J. C. J. (ed.) Marine interfaces ecohydrodynamics. Elsevier, Amsterdam, p. 195-213

Talbot, M. S. (1974). Distribution of euphausiid crustaceans from the Agulhas current. Zool. Afr. 9: 93-145

Torres, J. J., Childress, J. J. (1983). Relationship of oxygen consumption to swimming speed in Euphausia pacifica. 1. Effects of temperature and pressure. Mar. Biol. 74: 79-86

Venter, G. E. (1969). The pilchard of South West Africa (Sardinops ocellatus). The distribution of some chaetognaths and their relation to hydrological conditions with special reference to the South West African region of the Benguela Current. Investl Rep. mar. Res. Lab. S. W. Afr. 16:1-73

Verheye, H. M., Hutchings, L. (1988). Horizontal and vertical distribution of zooplankton biomass in the southern Benguela, May 1983. S. Afr. J. mar. Sci. 6: 255-265

Waldron, H. N. (1985). Influences on the hydrology of the Cape Columbine/St Helena Bay region. MSc. thesis, University of Cape Town

Williams, R., Lindley, J. A. (1982). Variability in abundance, vertical distribution and ontogenetic migrations of Thysanoessa longicaudata (Crustacea: Euphausiacea) in the North-Eastern Atlantic ocean. Mar. Biol. 69: 321-330

Williams, R., Fragopoula, N. (1985). Vertical distribution and nocturnal migration of Nyctiphanes couchi (Crustacea: Euphausiacea) in relation to the summer thermocline in the Celtic Sea. Mar. Biol. 89: 257-262

Wroblewski, J. S. (1982). Interaction of currents and vertical migration in maintaining Calanus marshallae in the Oregon upwelling zone - a simulation. Deep Sea Res. 29: 665-686

Manuscript first received: July 28, 1988

Revised version accepted: January 16, 1989 